\title{
MPL Gene
}

National Cancer Institute

\section{Source}

National Cancer Institute. MPL Gene. NCI Thesaurus. Code C18411.

This gene plays a regulatory role in megakaryocytopoiesis and platelet formation. 